\section{PERBEDAAN JENIS BAHAN PENYAMAK TERHADAP SIFAT FISIK KULIT KATAK BULL FROG}

Mochtar Lutfie *, Meiyanti *, Esti Rahayu*, Nur Endah* *

Abstract

The Obyective of this research is to study the effects of various tanning agents on the qualities of leather made from Bull Frog skin. Fifteen pieces of wet salted Bull Frog from Malang were tanned with several tanning agents, wich are mineral $(10 \%$ Chromosal B), vegetable were tanned with several tanning agents, wich are mineral (10\% Chromosal $B$ ), vegetable $(10 \%$ Mimosa extraxt) and syntetic tensile strengths and elongations. Its turned out that vegetable tanning agent gave the higest tensile strength $(279.62 \mathrm{~kg} / \mathrm{cm} 2)$, while mineral tanning agent gave the lowest one $(183.04 \mathrm{~kg} / \mathrm{cm} 2)$. It showed that the type of tannig agent lanning agent gave the lowest one 183.04 kg che le sther produced $(p \leq 0.005)$. On the used significantly effects the tensile strength of the learther prodiced ( $p \leq 0.005)$. On the other hand, mineral tanning agent gave the higest elongation $(105,20 \%)$. While vegetable tanning agent gave the lowest one $(91.20 \%)$. This result implied that the type of tanning agent used has a significant effect on the elongation $(p \leq 0,01)$.

\section{INTISARI}

Penelitian ini bertujuan untuk mengetahui kualitas kulit jadi dari kulit katak Bull Frog yang disamak dengan berbagai jenis bahan penyamak. Dengan menggunakan 15 lembar kulit katak Bull Frog awet garam basah yang berasal dari daerah Malang, disamak hingga kulit ratak Bull Frog a chomosal B), nabati (20\% minosa ekstrak) dan sintetis (20\% Irgatan LV). Kulit jadinya diuji secara fisis tentang kekuatan tarik dan kemuluran. Didapatkan hasil kekuatan tarik yang tertinggi adalah yang menggunakan bahan penyamak nabati $\left(279,62 \mathrm{~kg} / \mathrm{cm}^{2}\right)$, yang terendah bahan penyamak menggunakan bahan penyamak nabait $\left(279,62 \mathrm{~kg} / \mathrm{cm}^{2}\right)$, yang terendah bahan penyamak mineral $\left(183,04 \mathrm{~kg} / \mathrm{cm}^{2}\right)$, yang berarti penggunaan bahan penyamak yang berbeda berpengaruh nyata $(p \leq 0,05)$ terhadap kekuatan tarik. Hasil uji kemuluran nilai tertinggi didapatkan pada penyamakan yang menggunakan bahan penyamak mineral $(105,20 \%)$ dan terendah oleh bahan penyamak nabati $(91,20 \%)$. Perbedaan bahan penyamak berpengaruh sangat nyata $(p \leq 0,01)$ terhadap kemuluran.

\section{PENDAHULUAN}

Barang-barang jadi yang terbuat dari kulit sejak dahulu disukai masysrakat, karena mempunyai sifat khas yang tidak dimiliki oleh produk lainnya. Jenis kulit mentah banyak sekali mulai dari kulit lembar besar (hides) sampai kulit lembar kecil (skins) yang dapat digunakan sebagai bahan baku berbagai jenis barang kerajinan kulit . Kulit katak Bull Frog yang selama ini hanya sebagai limbah, ternyata hasil penelitian Muchtar Lutfie, dkk (1995) menunjukkan bahwa bisa digunakan

* BBKKP Yogyakarta

** Universitas Muhammadiyah Malang. nebagai bahan baku kulit karena mempunyai sifat fisis yang cukup tinggi.

Untuk mendapatkan produk kulit yang bermutu baik, selain diperlukan kulit mentah yang bermutu baik juga diperlukan proses pengolahan yang baik dan tepat (Soemarmi,dkk 1989), karena sifat-sifat teknis dari kulit jadi selain dipengaruhi/ ditentukan oleh bahan penyamaknya juga dipengaruhi oleh bahan-bahan yang dipergunakan dalam proses pengolahan. Berbeda jenis bahan penyamak yang digunakan maka berbeda pula sifat fisis maupun chemisnya (O'Flaherty, 1978).

Ada beberapa jenis bahan penyamak yang bisa menyamak kulit yang didapatkan yaitu : bahan penyamak mineral, penyamak sintetis, dan bahan penyamak nabati (Jayusman, 1989).Pada umumnya bahan penyamak mineral yang digunakan adalah bahan penyamak krom (Purnomo,1989).

Kulit yang disamak dengan bahan penyamak krom akan didapatkan kulit jadi yang lemas, tahan terhadap suhu tinggi dan kekuatan tariknya cukup tinggi pula. Kulit yang disamak dengan bahan penyamak nabati akan didapatkan kulit jadi yang tampak berisi, warna terang tetapi kaku. Sedangkan kulit yang disamak dengan bahan penyamak sintetis mempunyai sifat yang tidak jauh berbeda dengan kulit yang disamak dengan bahan penyamak nabati (Sharphouse, 1971).

Kekuatan secara umum menjadi ukuran dalam menentukan pemilihan ierhadap kulit yang sangat penting. Kekuatan menunjukkan kualitas daripada serat, kekuatan yang rendah menunjukkan kualitas serat yang jelek atau biasanya menyebabkan penurunan kualitas daripada kulit tersebut dan metoda penyamakan yang berbeda pula (O'Flaherty, 1978).

Sifat-sifat fisis kulit adalah ketahanan kulit terhadap pengaruh mekanik,kelembaban dan suhu kamar (Djojo widagdo, 1981). Sifat-sifat fisis kulit yang dapat diukur adalah kekuatan tarik, kemuluran, suhu kerut dan kuat tekuk atau kekakuan (Anonimous, 1971). Namun demikian yang paling dominan dalam pemakaian adalah kekuatan tarik dan kemuluran, seperti yng dikatakan oleh Mc. L anghlu dan Theis (1945) bahwa kekuatan tarik dan kemuluran merupakan syarat penting dalam hubungannya dengan kegunaan daripada kulit tersamak. Juga dikatakan oleh Aten, et al (1966) bahwa kekuatan tarik dan kemuluran kulit jadi sangat dipengaruhi oleh perubahan-perubahan struktur serabut kulit pada waktu proses penyamakan berlangsung.

Penelitian ini bertujuan untuk mengetahui kualitas kulit jadi dari kulit katak Iull Frog yang disamak dengan berbagai jenis bahan penyamak.

\section{MATERI DAN METODA}

MATERI

1. Kulit

Kulit yang digunakan adalah 15 lembar kulit katak Bull Frog berasal dari daerah Malang. 
2. Bahan Penyamak

Bahan penyamak yang digunakan pada penelitian ini adalah :

- Bahan penyamak mineral : Chromosal B

- Bahan penyamak nabati : Mimosa ekstrak.

- Bahan penyamak sintetis : Irgatan LV

3. Bahan Pembantu Penyamak

Bahan pembantu penyamak yang digunakan diantaranya ialah : Depan $\mathrm{B}, \mathrm{NaCl}$, $\mathrm{Na} 2 \mathrm{~S}$, Iragol DA, Oropon OR, $\mathrm{HCOOH}, \mathrm{H} 2 \mathrm{SO} 4, \mathrm{Na} 2 \mathrm{CO} 3$, Sandolix WWl, dll. 4. Peralatan.

Alat-alat yang digunakan diantaranya adalah : Pisau, paku, palu, papan, timbangan, mangkuk, ember, drum penyamakan, mesin buffing, dll.

\section{METODA}

Rancangan yang dipergunakan adalah Rancangan Acak Lengkap (RAL) dengan metode eksperimen. Pada rancangan ini digunakan 3 (tiga) perlakuan dengan lima kali ulangan.

Perlakuan yang diberikan adalah penggunaan berbagai jenis bahan penyamak yaitu : bahan penyamak mineral ( $10 \%$ Chromosal B), bahan penyamak nabati $(20 \%$ Mimosa ekstrak) dan bahan penyamak sintetis (20\% Irgatan LV).

Tata cara pelaksanaan proses sesuai dengan tata cara yang ada pada Kelompok Peneliti Proses Penyamakan Kulit, Balai Penelitian Barang Kulit di BBKKP.

Kulit jadi hasil penelitian diuji fisis tentang kekuatan tarik dan kemulurannya sesuai dengan SNI No. 06-1793-1989

Data yang diperoleh dianalisa dengan sidik ragam (uji F), kemudian jika terjadi perbedaan yang nyata diantara perlakuan dilanjutkan dengan BNT (Beda Nyata Terkecil).

\section{HASIL DAN PEMBAHASAN}

\section{A. Kekuatan Tarik}

Rata-rata kekuatan tarik kulit jadi dari kulit katak Bull Frog setelah dilakukan pengujian adalah sebagai berikut :
Tabel 1. Hasil Uji Kekuatan Tarik Kulit Jadi dari Kulit Katak Bull Frag (Kg/ $\mathrm{Cm} 2$ ).

\begin{tabular}{|l|c|c|c|}
\hline \multirow{2}{*}{ No. } & \multicolumn{3}{|c|}{ Bahan Penyamak } \\
\cline { 2 - 4 } 1. & Chromosal B & Mimosa Ekstrak & Irgatan LV \\
2. & 182,2 & 260,32 & 189,84 \\
3. & 181,59 & 333,33 & 194,29 \\
4. & 149,84 & 333,33 & 201,27 \\
5. & 168,89 & 307,94 & 68,89 \\
Jumlah & 232,67 & 163,17 & 202,54 \\
Rata-rata & 915,19 & $1.398,09$ & 956,83 \\
\hline
\end{tabular}

Rataan kekuatan tarik tertinggi dicapai oleh bahan penyamak nabati jenis mimosa ekstrak yaitu sebesar $279,62 \mathrm{~kg} / \mathrm{cm} 2$. Hasil analisis statistik menunjukkan hahwa penggunaan ketiga macam bahan penyamak yang berbeda berpengaruh nyata (P S 0,05) terhadap kekuatan tarik. Uji beda nyata terkecil menunjukkan kulit yang disamak dengan mimosa ekstrak berbeda sangat nyata dengan kulit yang disamak dengan Chromosal B dan Irgatan LV, sedang kulit yang disamak dengan bahan penyamak Chromosal B dan Irgatan LV tak berbeda nyata.

Penyamakan dengan bahan penyamak mimosa ekstrak memberikan rataan milai kekuatan tarik tertinggi dibandingkan dengan bahan penyamak lainnya, hal ini disebabkan karena zat penyamak nabati akan bereaksi dengan kolagan dan selanjutnya zat penyamak nabati akan meningkatkan ikatan serat-serat dari kulit dan merubah serat tunggal menjadi struktur kulit yang kompak. Sesuai dengan pendapat Purnomo (1989) bahwa kulit yang disamak dengan bahan penyamak nabati akan meningkatkan ikatan serat-serat dari kulit dan merubah serat tunggal menjadi struktur kulit yang kompak. Kulit yang disamak dengan bahan penyamak nabati akan memberikan hasil akhir ketahanan fisiknya terhadap panas kurang baik dibandingkan dengan kulit yang disamak dengan krom, walaupun lebih baik bila dibandingkan dengan kulit yang disamak dengan minyak atau formal dehid, kulitnya agak kaku namun empuk dan memberikan sifat kulit yang berisi (padat), warna coklat muda, kulitnya cukup lemas dan kekuatan tariknya tinggi.

$\mathrm{pH}$ awal pada proses penyamakan nabati adalah $\mathrm{pH}$ tinggi $( \pm 6)$ yang mana ini berpengaruh terhadap penetrasi zat penyamak nabati ke dalam kulit. Pada $\mathrm{pH}$ lingsi tersebut bahan penyamak nabati akan mempunyai zarah-zarah yang lebih halus bila dibandingkan dengan bahan penyamak yang ber $\mathrm{pH}$ rendah, hal ini menyebabkan zat penyamak mudah masuk ke dalam jaringan kulit, sehingga proses penyamakan nabati dapat berlangsung lebih sempurna. Pemasukan zat penyamak secara bertahap pada proses penyamakan nabati akan menghindarkan kulit 
mengalami kontraksi dan ini dapat menunjukkan bahwa prinsip golden rule telah terpenuhi yaitu penyamakan diawali dengan larutan encer, penetrasi cepat dan merata.

\section{B. Kemuluran}

Rata-rata persentase kemuluran kulit jadi dari kulit katak Bull Frog setelah dilakukan pengujian adalah seperti pada tabel 2 yaitu :

Tabel 2. Hasil uji kemuluran kulit jadi dari kulit katak Bull Frog (\%)

\begin{tabular}{|l|c|c|c|}
\hline \multirow{2}{*}{ No } & \multicolumn{3}{|c|}{ Bahan Penyamak } \\
\cline { 2 - 4 } & Chromosal B & Mimosa Ekstrak & Irgatan LV \\
\hline 1. & 100 & 90 & 96 \\
2. & 114 & 100 & 86 \\
3. & 114 & 84 & 98 \\
4. & 100 & 92 & 96 \\
5. & 98 & 90 & 92 \\
\hline Jumlah & 526 & 456 & 468 \\
\hline Rata-rata & 105,20 & 91,20 & 93,60 \\
\hline
\end{tabular}

Rataan nilai kemuluran tertinggi didapatkan pada kulit samak krom yaitu sebesar 105,2\% dan rataan terendah didapatkan kulit katak yang disamak dengan bahan penyamak mimosa yaitu $91,2 \%$. Analisis statistik menunjukkan bahwa bahan penyamak yang berbeda akan berpengaruh sangat nyata $(P \leq 0,01)$ terhadap kemuluran kulit jadi dari kulit katak Bull Frog. Uji Beda Nyata Terkecil menunjukkan bahan penyamak krom berbeda sangat nyata dengan bahan penyamak mimosa dan Irgatan LV, sedang bahan penyamak mimosa dan Irgatan LV tidak berbeda nyata.

Bahan penyamak krom memberikan kemuluran yang tertinggi, in disebabkan karena kulit yang tersamak ( yang tersusun oleh kolagen) dengan adanya penambahan bahan penyamak krom maka serat-serat penyusun kulit akan semakin terbuka atau longgar, karena semakin banyak kolagen yang tersamak oleh bahan penyamak mempunyai stabilitas yang tinggi dan zat penyamak krom yang bereaksi dengan kolagen akan menembus dan menetrasi ikatan-ikatan serat serta antar ikatan serat sehingga serat-seratnya lebih halus dan lebih elastis. Kulit jadi yang dihasilkan adalah lemas tetapi kosong, sesuai dengan yang diungkapkan oleh Gustavson (1956) bahwa kulit jadi yang disamak dengan bahan penyamak krom mempunyai ciri-ciri sebagai berikut : daya tahannya kuat terhadap panas, serat-seratnya halus dan mempunyai sifat elastis yang sangat baik, tetapi kulit akan mempunyai serat-serat yang kurang melekat secara erat dan juga agak kosong jika dibandingkan dengan kulit olahan yang disamak dengan ekstrak tumbuh-tumbuhan. Akibat keadaan kulit yang kosong, maka kekuatan tariknya rendah dan kemulurannya tinggi.

Rendah kemuluran yang didapatkan pada kulit yang disamak dengan bahan penyamak mimosa adalah akibat dari bahan penyamak nabati yang meningkatkan ikatan serat-serat dari kulit dan merubah serat tunggal menjadi struktur kulit yang kompak. Sesuai dengan pendapat Purnomo (1989) bahwa kulit yang disamak dengan bahan penyamak nabati akan didapatkan kulit yang padat, berisi tetapi kaku, sehingga kemulurannya rendah tetapi kekuatan tariknya tinggi.

Dari tabel 1 dan 2 didapatkan bahwa kekuatan tarik dan kemuluran berbanding secara terbalik di mana kekuatan tarik yang tinggi menunjukkan kemulurannya rendah dan sebaliknya. kekuatan tariknya rendah menunjukkan kemulurannya tinggi. O'Flaherty (1978) menyebutkan, data yang berasal dari test kekuatan tarik dan kemuluran akan berbanding secara terbalik. apabila suatu kemuluran tinggi maka kekuatan tariknya rendah demikian pula sebaliknya.

Langkah terbaik yang dapat diambil dalam penyamakan kulit katak Bull Frog adalah dengan menggabungkan bahan penyamak tersebut, sehingga nilai kekuatan tarik dan kemuluran yang tinggi dapat diperoleh.

Wynn (1965) menyatakan bahwa kulit chrome yang disamak dengan bahan penyamak nabati akan menghasilkan kulit yang mempunyai sifat lebih berisi.

Lebih lanjut Sharphouse (1971) dan Lutfie (1988) menjelaskan bahwa penyamakan secara kombinasi dapat memberikan sifat-sifat dari bahan yang diberikan, bahan samak krom sifatnya lemas tapi kosong, sedangkan bahan samak nabati padat tetapi kaku.

\section{KESIMPULAN DAN SARAN}

\section{Kesimpulan}

Dilihat dari uraian hasil dan pembahasan, dapat disimpulkan bahwa kekuatan tarik tertinggi dicapai oleh bahan penyamak nabati (mimosa) sebesar 279,62 kg $\mathrm{cm} 2$ dan persentase kemuluran tertinggi adalah bahan penyamak mineral (chromosal II sebesar 105,20\%)

Saran

Setelah diketahui bahwa jenis bahan penyamak yang berbeda memberikan infat fisis yang berbeda, maka disarankan dilakukan penelitian lebih lanjut tentang penyamakan kombinasi, karena dimungkinkan dengan penyamaan kombinasi kekurangan dari satu bahan penyamak akan dapat dilengkapi oleh bahan penyamak lainnya.

\section{DAFTAR PUSTAKA}

1. Annomious : Proses Penyamakan Kulit, BBKKP, Yogyakarta, 1971.

2. Aten,A.,F. Innes and E. Knew : Flying and Curing of Hider and Skins as a Rural 
Industry, Food and Agriculture Organization of the United Nations, Rome, Italy, 1966.

3. Djojowidagdo, S. Kulit Kerbau Sebagai Bahan untuk Pembuatan Wayang Kulit Ditinjau dari Struktur Jaringan, Susunan Kimia dan Sifat-sifat Fisiknya. Usulan Disertasi dalam Bidang Peternakan - Fakultas Peternakan Universitas Gadjah Mada, Yogyakarta, 1981.

4. Gasperz, V. : Metode Perancangan Percobaan, Armico,Bandung, 1991.

5. Gustavson, K.H. : The Chemistry and Reactivity of Collagen, Academic Press.Inc.Publishers. New York, 1956.

6. Jayusman : Pengetahuan Bahan . Balai Penelitian Kulit, Yogyakarta, 1989.

7. Lutfie, M. Penyamakan Kulit Reptil (Kombinasi antara Bahan Penyamak Krom dan Sintetis). Balai Besar Penelitian dan Pengembangan Industri Barang Kulit, Karet dan Plastik, Yogyakarta, 1988.

8. Lutfie, M. dkk : Pengaruh Pengawetan Pada Sifat Fisis Kulit Kras Katak Bull Frog. Proceedings Seminar Sehari Mutu Kulit dan Produk Kulit Untuk Ekspor, BBKKP. Yogyakarta, 1995.

9c. Laughlin, C.D dan E.R. Theis : The Chemistry of Leather Manufacture, Reinhold Publishing Corporation, New York, U.S.A., 1945.

10. O'Flaherty, F. The Chemistry and Technology of Leather, Vol II, Reinhold Publishing Corporation, New York, 1956.

11. Purnomo, E. : Pengetahuan Dasar Technologi Penyamakan Kulit, Akademi Teknologi Kulit, Yogyakarta, 1989.

12. Sharphouse, J.H. : Leather Technician's Hand Book, Leather Product Association, London, 1971

13. Soemarni, dkk, : Pedoman Pengawetan Kulit Mentah, Kanisius, Yogyakarta, 1989.

14. Wynn, W.D.A. : Suggestion for The Use of Mimosa Extract for Retanning, Wattle Eksport Development, Sardinia House, London, 1965. 